\title{
UJI AKTIVITAS EKTRAK DAUN PALADO (Agave angustifolia) SEBAGAI ANTIOKSIDAN
}

\author{
Antioxidant Activity Test of Palado Leaves (Angave agustifolia) Extract
}

*Kurniati Nur, Anang W. M. Diah, dan Siti Nuryanti

Pendidikan Kimia/FKIP - Universitas Tadulako, Palu - Indonesia 94118

Received 11 March 2016, Revised 11 April 2016, Accepted 10 May2016

\begin{abstract}
Study on the antioxidant activity test has been conducted using palado (agave angustifolia) leaves from Tondo, Central Sulawesi. Palado plant is one of the succulent plants that can grow to a large size, and it is possible to contain antioxidant compounds. This study was conducted by an experimental method using maceration extraction technique and 1,1-difenil-2-picrylhydrazyl (DPPH) as the free radicals source, and vitamin $C$ as the positive control, whereas UV-Vis spectrophotometer as for determining wavelength $(\lambda)$ of palado leaves extracts. Sample used as much as 5 grams Palado leaves, and methanol as the solvent. Variation concentrations of palado leaves extract were 20,40,60,80,100, 120 , and $140 \mathrm{ppm}$. The results showed that the $I C_{50}$ value of palado leaves extract was $26.182 \mathrm{ppm}$. Palado leaves extract is classified as a very powerful antioxidant based on the $I C_{50}$ value. The optimum percentage antioxidant activity of palado leaves extract in inhibiting free radicals was by $84.84 \%$.
\end{abstract}

Keywords: Antioxidant, palado leaves, DPPH, spectronic UV-Vis.

\section{Pendahuluan}

Bahan pangan merupakan kebutuhan pokTanaman palado merupakan tanaman sukulen yang dapat tumbuh sampai berukuran besar. Spesies palado banyak ditanam sebagai pagar karena daunya memiliki duri sehingga sulit di lalui manusia maupun hewan. Selain itu, daun palado tersusun dari serat yang kuat sehingga dapat dibuat menjadi tali atau anyaman. Pada penelitian sebelumnya diduga adanya enzim protease dalam akar dan daun Palado yang digunakan untuk mendegradasi ikatan lipoprotein pada santan seperti halnya enzim bromelin yang terdapat dalam tanaman nanas. Uji terhadap ekstrak enzim daun palado yang diperoleh dalam proses pembuatan Virgin Coconut Oil (VCO) serta rendemen dan kualitas (VCO) yang dihasilkan untuk mengindentifikasi bilangan asam dari VCO (Dewi \& Rahmawati, 2012).

Penelitian tentang pemanfaatan daun Palado hingga kini belum banyak dilakukan. Penelitian yang dilakukan hanya sebatas pemanfaatan enzim protease dalam daun

\section{*Correspondence:}

Kurniati Nur

Program Studi Pendidikan Kimia, Fakultas Keguruan dan

Ilmu Pendidikan, Universitas Tadulako

email: kurniatinur282@yahoo.co.id

Published by Universitas Tadulako 2016 palado untuk pembuatan (VCO) dan belum mengindentifikasi adanya senyawa-senyawa aktif seperti antioksidan (Nadira, 2013)

Studi tersebut menjelaskan adanya kemungkinan senyawa antioksidan yang terkandung di dalam daun Palado yang mempunyai gugus yang sama seperti enzim protease (gugus asam dan amino). Senyawa antioksidan dalam daun tersebut dapat dimanfaatkan sebagai antibiotik, antikanker, antikoagulan darah dan menghambat efek karsinoginik. Selain itu juga dapat dimanfaatkan sebagai anti agen pengendali hama yang ramah lingkungan (Samsuddin \& Khoiruddin, 2008).

Penelitian tentang uji kualitatif senyawa metabolit sekunder pada daun palado (agave angustifolia) yang diekstraksi dengan pelarut air dan etanol dengan menggunakan metode maserasi. Penelitian ini bertujuan untuk mengetahui kandungan kimia daun palado. Metode yang digunakan yaitu skrining fitokimia (uji kualitatif) dengan cara uji tabung untuk menentukan jenis senyawa aktif yang terkandung di dalam tanaman. Kandungan kimia yang diuji pada penelitian ini adalah alkaloid, terpenoid, steroid, flavonoid, dan tanin. Komponen yang terdapat dalam ekstrak air dan etanol daun palado dianalisis golongan senyawanya dengan tes uji warna 
menggunakan beberapa pereaksi untuk golongan senyawa alkaloid, flavonoid, steroid, terpeneoid, dan tanin. Pereaksi-pereaksi spesifik yang digunakan berinteraksi dengan sampel berdasarkan prinsip "like dissolve like". Hasil penelitian menunjukkan ekstrak air dan ekstrak etanol daun palado mengandung komponen kimia yakni alkaloid, flavonoid dan tanin. Penelitian yang diperoleh yaitu daun palado yang diekstraksi dengan menggunakan pelarut air dan etanol mengandung senyawa metabolit sekunder yaitu alkaloid, flavonoid, dan tanin. $\mathrm{Hal}$ ini menunjukkan bahwa pelarut air juga bisa digunakan untuk mengekstrak senyawa metabolit sekunder pada tumbuhan, khususnya daun palado. Oleh karena itu, perlu dilakukan uji aktivitas antioksidan pada daun palado yang di ekstraksi dengan pelarut methanol (Ergina, 2014).

\section{Metode}

\section{Alat dan Bahan}

Peralatan yang digunakan pada penelitian ini yaitu Blender (Toshiba), gelas kimia $50 \mathrm{~mL}$, gelas ukur $50 \mathrm{~mL}$, labu ukur $50 \mathrm{~mL}$, neraca digital, oven, kertas saring, corong pemisah, spatula, batang pengaduk, pipet tetes dan spektrofotometer UV-Vis ( $P G$ instrumen Ltd). Bahan yang digunakan pada penelitian ini yaitu Daun palado, methanol (Merck), DPPH (Merck) dan Vitamin C (Merck).

\section{Tahapan-tahapan dalam prosedur untuk pengujian-pengujian berikut dikutip dari Tonahi, (2014).}

\section{Pembuatan Larutan DPPH 0,5 mM}

Sebanyak 9,8 mg DPPH dilarutkan dengan metanol dalam labu ukur $50 \mathrm{~mL}$, kemudian dicukupkan volumenya dengan metanol sampai tanda batas.

\section{Pembuatan Larutan Induk ekstrak daun palado}

Sebanyak $50 \mathrm{mg}$ ekstrak daun palado dilarutkan dalam labu ukur $50 \mathrm{ml}$ dengan pelarut metanol kemudian volumenya dicukupkan dengan metanol sampai tanda batas.

\section{Pembuatan Larutan Pembanding Vitamin C}

Sebanyak $50 \mathrm{mg}$ vitamin C dilarutkan dengan aquades kemudian dimasukkan ke dalam labu ukur $50 \mathrm{~mL}$ dan ditambahkan metanol sampai tanda batas.

\section{Larutan Uji \\ Larutan Induk ekstrak daun palado (20, 40, $60,80,100,120,140)$ ppm}

Sebanyak $1 \mathrm{~mL}, 2 \mathrm{~mL}, 3 \mathrm{~mL}, 4 \mathrm{~mL}, 5 \mathrm{~mL}, 6$ $\mathrm{mL}$ dan $7 \mathrm{~mL}$ dimasukkan kedalam labu ukur $50 \mathrm{~mL}$. Larutan masing-masing ditambahkan $5 \mathrm{~mL}$ larutan DPPH Kemudian ditambahkan metanol sampai tanda batas. Setelah itu larutan masing-masing diukur dengan menggunakan spektrofotometer UV-Vis pada panjang gelombang $517 \mathrm{~nm}$.

Larutan pembanding Vitamin C (20, 40, 60, $80,100,120,140) p p m$

Sebanyak $1 \mathrm{~mL}, 2 \mathrm{~mL}, 3 \mathrm{~mL}, 4 \mathrm{~mL}, 5 \mathrm{~mL}, 6$ $\mathrm{mL}$ dan $7 \mathrm{~mL}$ dimasukkan kedalam labu ukur $50 \mathrm{~mL}$. Larutan masing-masing ditambahkan 5 mL larutan DPPH Kemudian ditambahkan metanol sampai tanda batas. Setelah itu larutan masing - masing diukur dengan menggunakan spektrofotometer UV-Vis pada panjang gelombang $517 \mathrm{~nm}$.

\section{Pengukuran Serapan Blanko}

pengukuran dilakukan dengan cara memipet $5 \mathrm{~mL}$ DPPH dan dicukupkan volumenya sampai $50 \mathrm{~mL}$ dengan metanol dalam labu ukur. Larutan ini kemudian dihomogenkan dan dibiarkan selama 25 menit, selanjutnya diukur absorbansinya dengan spektrofotometri UV-Vis pada panjang gelombang $517 \mathrm{~nm}$. Semua pengerjaan dilakukan pada ruang yang terhindar dari cahaya matahari.

\section{Analisa Data}

Pengukuran Daya Antioksidan Ekstrak Daun Palado dan Larutan Pembanding Vitamin C.Besarnya Daya antioksidn dihitung dengan rumus, (Zuhra dkk., 2008).

Daya Antioksidan $=\frac{\text { absorbansi blanko } 0 \text { - absorbansi sampel }}{\text { absorbansi blanko }} \times 100 \%$

\section{Hasil dan Pembahasan \\ Hasil Ekstraksi Daun Palado Dengan Menggunakan Larutan Metanol}

Ekstraksi merupakan suatu proses selektif yang dilakukan untuk mengambil zat-zat yang terkandung dalam suatu campuran dengan menggunakan pelarut yang sesuai. Metode pemisahan ini bekerja berdasarkan prinsip kelarutan, yaitu pelarut polar akan melarutkan zat polar, dan sebaliknya (Khopkar, 2003).

Tahap awal yang dilakukan pada penelitian ini yaitu menyiapkan sampel daun palado dengan cara mencuci bersih daun palado. Kemudian memotongnya menjadi kecil-kecil. 
Tahap selanjutnya yaitu mengeringkan daun palado kedalam oven. Proses ini bertujuan untuk menghilangkan kadar air pada sampel daun palado, selain itu juga agar senyawa metabolit sekunder yang terkandung oleh daun palado tidak rusak. Pengeringan cara ini berpengaruh terhadap mutu simplisia dan zat yang berkhasiat yang ada di dalamnya (Karyadi, 2004). Selanjutnya sampel daun palado yang sudah kering kemudian dihaluskan dengan menggunakan blender.

Tahap selanjutnya yaitu serbuk daun palado ditimbang sebanyak 5 gram kemudian diekstraksi dengan menggunakan pelarut metanol sebanyak $50 \mathrm{~mL}$. Penggunaan pelarut metanol ini, karena pelarut tersebut sudah umum digunakan untuk melarutkan senyawasenyawa metabolisme sekunder dalam bahan alam. Selain itu ekstraksi efektif jaringan tumbuhan yaitu menggunakan pelarut yang sesuai 10 kali volume atau bobot sampel, sehingga pada penelitian ini digunakan pelarut metanol sebanyak $50 \mathrm{~mL}$ untuk 5 gram sampel daun palado. Proses ekstraksi dilakukan dengan proses maserasi selama 3 x 24 jam. Selanjutnya dilakukan proses penyaringan menggunakan kertas saring untuk memperoleh filtrat yang selanjutnya digunakan untuk menguji aktivitas atioksidannya (Harbome, 1987)

\section{Uji Aktivitas Antioksidan daun palado}

Pada penelitian ini uji aktivitas antioksidan pada ekstrak daun palado menggunakan metode pengujian DPPH (1,1-difenil-2-pikrilhidrazil). Metode uji antioksidan menggunakan DPPH adalah salah satu metode uji kuantitatif untuk mengetahui seberapa besar aktivitas daun palado sebagai antioksidan. Metode ini merupakan metode yang telah lama digunakan untuk penetapan aktivitas senyawa antioksidan. Metode ini pengerjaanya juga mudah, cepat dan sensitif untuk menguji aktivitas antioksidan dari ekstrak tanaman menggunakan $\mathrm{DPPH}$ secara spektrofotometer (Pourmourand dkk., 2006).

Pengukuran aktivitas antioksidan untuk konsentrasi ekstrak daun palado yaitu (20, $40,60,80,120$ dan 140) ppm menggunakan spektrofotometer UV VIS pada panjang gelombang $517 \mathrm{~nm}$. Penggunaan panjang gelombang $517 \mathrm{~nm}$ merupakan panjang gelombang maksimum DPPH. Berdasarkan hasil yang diperoleh yaitu diketahui pada konsentrasi 20 ppm - 80 ppm nilai absorbansinya menurun sehingga diketahui daya antioksidannya tinggi. Hal tersebut dikarenakan, kemampuan antioksidan DPPH dalam menangkap radikal bebasnya meningkat. Selain itu, dikarenakan pada konsentrasi tinggi, senyawa yang terkandung akan semakin banyak dan menyebabkan semakin besar pula aktivitas antioksidannya. Reaksi DPPH dalam menangkap radikal bebas dapat dilihat pada Gambar 1. Melalui reaksi tersebut, reaksi penangkapan radikal bebas oleh senyawa antioksidan melalui mekanisme donasi atom hidrogen sehingga akan dihasilkan DPPH-H (non radikal).

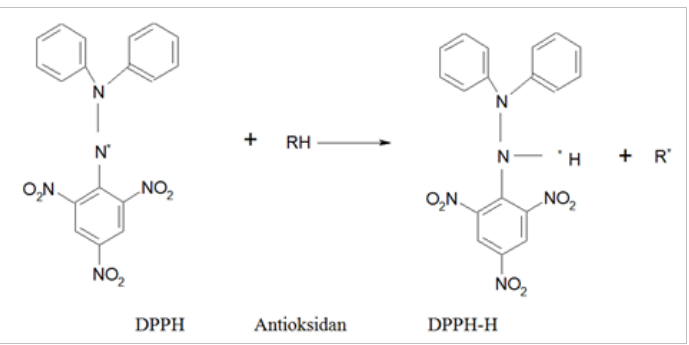

Gambar 1. Reaksi penangkapan radikal bebas oleh DPPH (Null, 1994)

Hasil pengukuran absorbansi ekstrak daun palado dapat menunjukkan pada konsentrasi 100 - 140 ppm, terlihat absorbansinya mulai meningkat. Hal tersebut dikarenakan pada konsentrasi tersebut kemampuan daya antioksidannya menurun. Hasil pengukuran absorbansi ekstrak daun palado dapat diilustrasikan pada Gambar 2

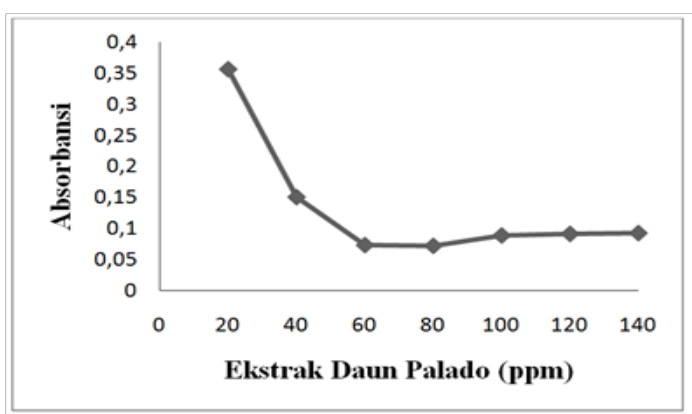

Gambar 2. Nilai Absorbansi DPPH terhadap Ekstrak Daun Palado

Berdasarkan grafik pada Gambar 2, diketahui konsentrasi ekstrak daun palado pada $20-80$ ppm semakin meningkat sehingga diperoleh nilai absorbansinya menurun. Hal tersebut dikarenakan semakin tinggi konsentrasi ekstrak daun palado maka partikel-partikel senyawa antioksidan yang terkandung akan semakin banyak sehingga sehingga semakin besar pula aktivitas antioksidannya dan menyebabkan absorbansinya semakin berkurang. Setelah itu 
dilihat dari perbedaan dari intensitas warna dari beberapa konsentrasi, dimana pada konsentrasi 80 ppm memiliki warna kuning paling terang. Namun pada konsentrasi 100 sampai 140 ppm absorbansinya meningkat, Hal ini dikarenakan pada konsentrasi larutan sampel tersebut kurang baik aktivitas antioksidannya sehingga absorbansinya meningkat (Talapessy dkk., 2013).

Berdasarkan nilai absorbansi ekstrak daun palado maka diperoleh pula aktivitas antioksidan berdasarkan persentase penghambatanya yang dapat diilustrasikan pada Gambar 3. Konsentrasi DPPH juga semakin menurun. Hal tersebut menandakan bahwa daya penghambatan radikal bebas oleh antioksidan ekstrak daun palado semakin meningkat dengan konsentrasi $80 \mathrm{ppm}$ sementara 100 ppm -140 ppm mengalami penurunan. Data tersebut menunjukkan bahwa titik optimal atau optimum aktivitas antioksidan ekstrak daun palado berada pada konsentrasi $80 \mathrm{ppm}$ yang mempunyai persentase penghambatan radikal sebesar $84,84 \%$. Hasil persentase penghambatan radikal bebas ini mendukung hasil pengamatan warna larutan DPPH setelah ditambahkan ke dalam ekstrak daun palado. Warna DPPH yang berkurang lebih banyak memiliki persentase penangkapan radikal bebas, yang berarti bahwa cahaya lebih banyak diteruskan dan cahaya yang diserap lebih sedikit.

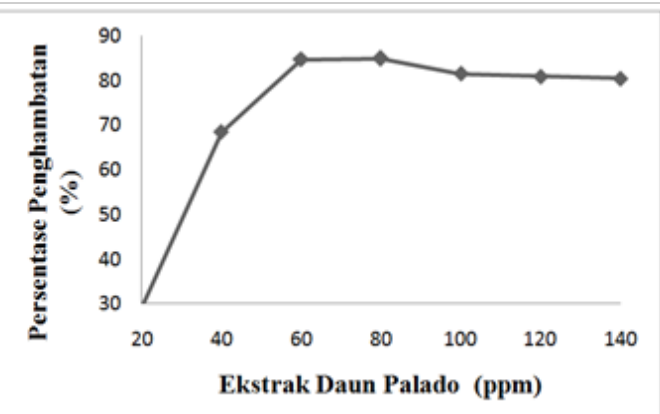

Gambar 3. Kurva Aktivitas Antioksidan ekstrak daun palado

\section{Uji Aktivitas Antioksidan Vitamin C}

Perlakuan uji aktivitas antioksidan vitamin C dilakukan untuk dapat membandingkan aktivitas antioksidannya terhadap antioksidan ekstrak daun palado melalui variasi konsentrasi yang sama yaitu $(20,40,60,80,120$ dan 140) ppm. Hasil penelitian yang dilakukan memperoleh nilai absorbansi dari DPPH yang diilustrasikan pada Gambar 4. Peningkatan konsentrasi vitamin $\mathrm{C}$ dari $(20,40,60,80$,
120 dan 140) ppm mempengaruhi tingkat kemampuan vitamin $\mathrm{C}$ untuk meredam radikal bebas DPPH sehingga nilai absorbansinnya semakin menurun. Dengan kata lain semakin tinggi konsentrasi vitamin $\mathrm{C}$ maka semakin kuat vitamin $\mathrm{C}$ dalam menangkap radikal bebas DPPH. Hal ini sesuai dengan penelitian sebelumnya yang menggunakan vitamin $\mathrm{C}$ sebagai pembanding tingkat antioksidannya terhadap daun sirih merah, yang juga menunjukkan bahwa peningkatan konsentrasi vitamin $\mathrm{C}$ mempengaruhi peningkatan antioksidannya (Tonahi, 2014).

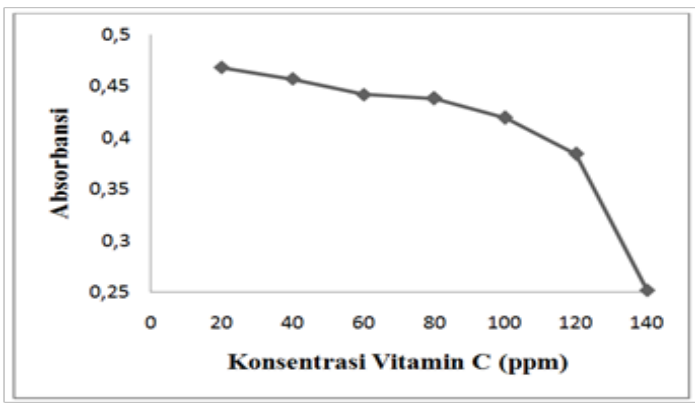

Gambar 4. Absorbansi DPPH terhadap vitamin C.

Berdasarkan absorbansi yang diperoleh maka diperoleh juga persentase penghambatan aktivitas antioksidan dari vitamin $\mathrm{C}$ yang diilustrasikan pada Gambar 5. Peningkatan konsentrasi vitamin $\mathrm{C}$ dari $(20,40,60,80$, 120 dan 140) ppm mempengaruhi tingkat persentase penghambatan vitamin $\mathrm{C}$. Hal tersebut menunjukkan bahwa semakin besar konsentrasi vitamin $\mathrm{C}$ maka semakin besar pula persentase penghambatan radikal bebas DPPH. kemampuan vitamin $\mathrm{C}$ untuk meredam radikal bebas DPPH sehingga nilai absorbansinnya semakin menurun. Berdasarkan hasil yang diperoleh persentase penghambatan tertinggi terdaapt pada konsentrasi $140 \mathrm{ppm}$ dengan persentase penghambatan sebesar $46,94 \%$.

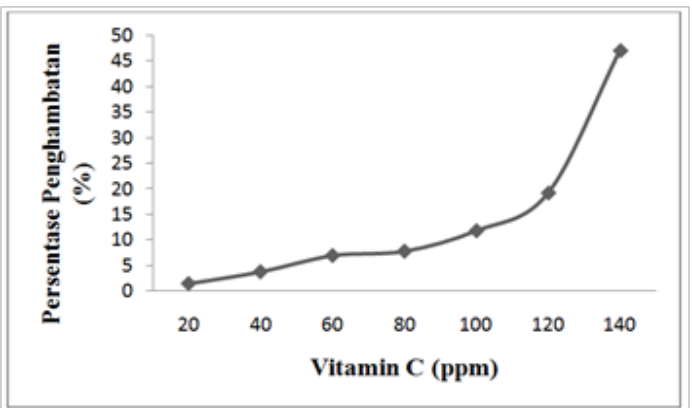

Gambar 5. Aktivitas Antiosidan Vitamin C 
Perbandingan Aktivitas Penangkap Radikal Bebas Ekstrak Daun Palado Dengan Kontrol Vitamin C.

Hasil penelitian ini membandingkan aktivitas antioksidan antara ekstrak daun palado dan vitamin C sebagai kontrol positif memiliki perbedaan yang jauh, Persentase penangkap radikal bebas dari sampel ekstrak daun palado yang menjadi tinjauan utama dalam penelitian ini berbeda jauh dengan persentase penangkap radikal bebas dari vitamin $\mathrm{C}$ yang merupakan pembanding (kontrol positif). Perbandingan persentase penangkap radikal bebas dari ekstrak daun palado dan vitamin $\mathrm{C}$ dapat dilihat pada Gambar 6.

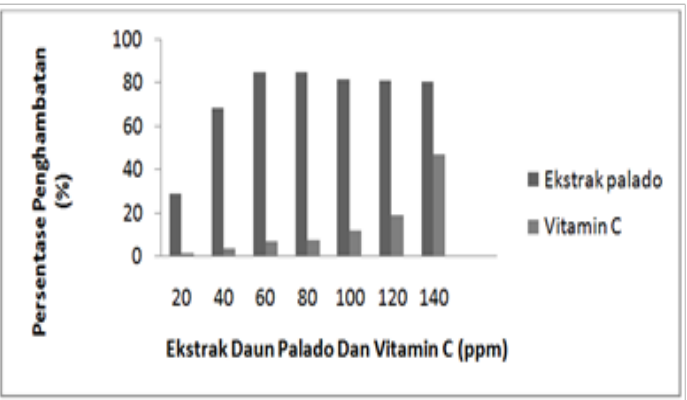

Gambar 6. Perbandingan persentase

Penghambatan Ekstrak Daun Palado dan Vitamin C

Gambar 6 memperlihatkan persentase radikal bebas dari vitamin $\mathrm{C}$ memiliki perbedaan dengan ekstrak daun palado, bahkan persentase penghambatan ekstrak daun palado melampaui persentase penghambatan vitamin C. Berdasarkan hal ini maka dapat diketahui bahwa ekstrak daun palado mempunyai aktivitas antioksidan sehingga dapat dijadikan sebagai zat antioksidan alami.

\section{Pengukuran $I C_{50}$ Ekstrak Daun Palado}

Uji antioksidan dalam penelitian ini menggunakan parameter $\mathrm{IC}_{50}$ ( $\neg$ Inhibition concentration) untuk menginterpretasikan hasil pengujian dengan metode DPPH. IC50 merupakan konsentrasi substrat atau sampel yang akan menyebabkan reduksi terhadap aktivitas DPPH (1,1-difenil-2-pikrilhirazil) sebesar 50\% (Molyneux, 2004). Semakin kecil nilai $\mathrm{IC}_{50}$ berarti semakin tinggi aktivitas antioksidan. Nilai $\mathrm{IC}_{50}$ diperoleh dari beberapa tahapan yaitu menghitung nilai log konsentrasi dan nilai probit untuk masing-masing persentase aktivitas penghambat radikal bebas DPPH. Selanjutnya menghubungkan kedua data dari perhitungan yang diperoleh dalam 1 grafik utuh, dimana nilai log konsentrasi dijadikan sebagai sumbu $\mathrm{x}$ dan nilai probit digunakan sebagai sumbu y. Adapun dalam hal ini dapat dilihat pada Gambar 7

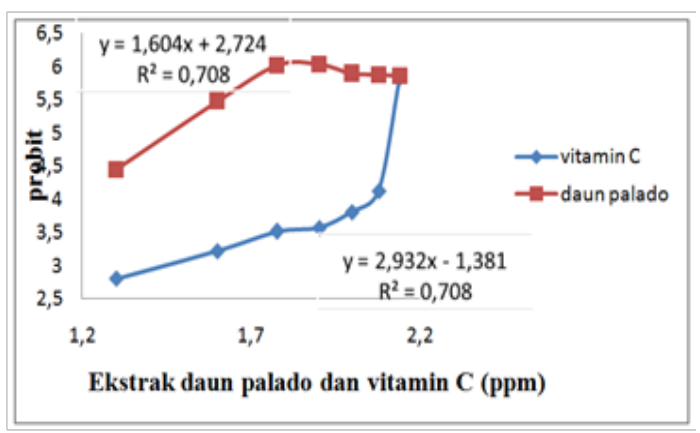

Gambar 7 Hubungan Log Konsentrasi antara Probit vitamin C dan Ekstrak daun palado

Berdasarkan Gambar 7 dapat diperoleh persamaan regresi linear $\mathrm{Y}=2,932 \mathrm{x}-1,381$ untuk vitamin $\mathrm{C}$ dan $\mathrm{Y}=1,604 \mathrm{x}+2,724$ untuk ekstrak daun palado (sampel) (Pembanding/ kontrol positif). Berdasarkan Gambar 4.8 dan 4.9 dapat diperoleh nilai $r$ untuk ekstrak daun palado dan Vitamin C sebagai control positif yaitu masing-masing 0,708 dan 0,696. Dari tinjauan literatur jika grafik hasil perhitungan memiliki nilai $r$ mendekati 1 atau sama dengan 1, maka data hasil penelitian yang diperoleh cukup baik. Hal ini kemungkinan disebabkan 3 hal, yaitu: (i) Kurang baiknya pembuatan deret konsentrasi larutan yang digunakan, (ii) Instrumen (Spektrofotometer Uv-Vis yang tidak dikalibrasi secara benar, dan (iii) Pegotor dalam kuvet yang digunakan sebagai tempat awal larutan, (Hariyatmi., 2004)

Nilai IC $_{50}$ yang diperoleh dari hasil perhitungan akhir yaitu untuk ekstrak daun palado mempunyai $\mathrm{IC}_{50}$ yang diperoleh dari hasil perhitungan akhir yaitu untuk ekstrak daun palado mempunyai $\mathrm{IC}_{50}$ sebesar 26,182 ppm sedangkan $\mathrm{IC}_{50}$ yang dihasilkan vitamin C sebesar 149,968 ppm. Hal ini menjelaskan bahwa kemampuan menangkap radikal bebas ekstrak daun palado termasuk golongan sangat kuat dikarnakan nilai $\mathrm{IC}_{50}$ yang diperoleh dari perhitungan kurang dari 50 ppm yaitu $26,182 \mathrm{ppm}$. Hal ini sesuai dengan literatur yang mengatakan bahwa tingkat kekuatan antioksidan menggunakan metode $\mathrm{DPPH}$ dapat digolongkan menurut $\mathrm{IC}_{50}$. Antioksidan sangat kuat jika nilai $\mathrm{IC}_{50}$ kurang dai $50 \mathrm{ppm}$, kuat jika $\mathrm{IC}_{50}$ bernilai 50-100 ppm, sedang jika $\mathrm{IC}_{50}$ bernilai $100-150 \mathrm{ppm}$, dan lemah jika IC50 bernilai 150-200 ppm (Kumalaningsih, 2006). Semakin kecil nilai $\mathrm{IC}_{50}$ berarti semakin 
kuat daya antioksidan.

Berdasarkan nilai $\mathrm{IC}_{50}$ yang diperoleh dapat dijelaskan pula bahwa ekstrak daun palado termasuk antioksidan yang lebih kuat jika dibandingkan dengan vitamin $\mathrm{C}$ sebagai pembanding atau kontrol positif. Ini menunjukkan bahwa daun palado dapat digunakan sebagai antioksidan alami

\section{Kesimpulan}

Ekstrak daun palado (agave angustifolia) dapat berperan sebagai antioksidan alami dan termasuk golongan antioksidan yang sangat kuat berdasarkan nilai $\mathrm{IC}_{50}$ yang diperoleh 26,182 ppm dan dapat digunakan sebagai antioksidan alami.

\section{Ucapan Terima Kasih}

Penulis mengucapkan terima kasih kepada Laboratorium Agroteknologi Fakultas Pertanian Universitas Tadulako dan Laboratorium Kimia Fakultas Keguruan dan Ilmu Pendidikan Universitas Tadulako serta semua pihak yang telah membantu dalam pelaksanaan penelitian ini.

\section{Referensi}

Dewi, S., \& Rahmawati. (2012). Pemamfaatan protease dari akar agave daun palado (agave) dan daun nenas pada proses pembuatan virgin coconut oil (VCO). Jurnal Matematika dan Sains, 8(2), 231-238.

Ergina. (2014). Uji kualitatif senyawa metabolit sekunder pada daun palado (agave angustifolia) yang diekstraksi dengan pelarut air dan etanol. Universitas Tadulako, Palu.

Harbome, J. B. (1987). Metode fitokimia penentuan cara modern menganalisis tumbuhan. Bandung: ITB.

Hariyatmi. (2004). Kemampuan vitamin E sebagai antioksidan terhadap radikal bebas pada lanjut usia. Jurnal MIPA, 14(3), 52-60.

Karyadi. (2004). Antioksidan resep sehat dan umur panjang. Retrieved diunduh kembali dari www.indomedia.com/1997/juni/ antioksi.htm:24. Di akses 28 Desember 2014.
Khopkar, S. M. (2003). Konsep dasar kimia analitik. Jakarta: UI-Press.

Kumalaningsih, S. (2006). Antioksidan alami. Surabaya: Trubus Agrisarana.

Molyneux, P. (2004). The use of the stable free radical diphenylpicrylhydrazyl (DPPH) for estimating antioxidant activity. Journal of Scientific Computing International Technology, l.26(2), 211-219.

Nadira, S. (2013). Pemamfaatan daun palado (agave sp) dalam proses pembutan virgin coconut oil (vco). Universitas Tadulako Palu, Sarjana Pendidikan Pada FKIP.

Null. (1994). Antioksidan jenis sumber mekanisme kerja dan peran terhadap kesehatan. Bogor: Institut Pertanian Bogor Press.

Pourmourand, F., Hosseinimehr, S., \& Shahabimajd, N. (2006). Antioxidant activity, phenol and flavonoid contents of some selected Iranian medicinal plants. African Journal of Biotechnology, 5(11), 1142-1145

Samsuddin, A. M., \& Khoiruddin. (2008). Ekstraksi filtrasi membran dan uji stabilitas zat warna dari kulit manggis (garcinia mangostana). Universitas Diponegoro.

Talapessy, S., Suryanto, E., \& Yudistira. (2013). Uji aktivitas antiosidan dari ampas hasil pengolahan sagu (metroxylon sagu rottb). Jurnal Ilmiah Farmasi, 2(3), 40-44.

Tonahi, J. M. M. (2014). Antioksidan dari daun sirih (piper crocatum). Universitas Tadulako, Palu.

Zuhra, C. F., Taringan, J. B., \& Sihotang, H. (2008). Aktivitas antioksidan senyawa flavonoid dari daun katuk (sauropus androgunus (L) merr.). Jurnal Biologi Sumatera, 3(1), 7-10. 